\title{
Mastering the jazz standard: sayings and doings of artistic valuation
}

\author{
Erik Nylander
}

\section{Linköping University Post Print}

\section{Tweet}

N.B.: When citing this work, cite the original article.

Original Publication:

Erik Nylander, Mastering the jazz standard: sayings and doings of artistic valuation, 2013, American Journal of Cultural Sociology, (2), 1.

http://dx.doi.org/10.1057/ajcs.2013.13

Copyright: Palgrave Macmillan

http://www.palgrave-journals.com/pal/index.html

Postprint available at: Linköping University Electronic Press

http://urn.kb.se/resolve?urn=urn:nbn:se:liu:diva-102523 


\title{
Mastering the Jazz Standard
}

- Sayings and Doings of Artistic Valuation

\author{
Erik Nylander ${ }^{1}$
}

${ }^{1}$ Department of Behavioral Sciences and Learning, Linköping University, Linköping, Sweden 


\begin{abstract}
This article examines music auditions of jazz education and the artistic valuation of music performances by gatekeepers working in two prestigious schools. Using the inherent insecurities of the entry-test situation as a site of ethnographic fieldwork, the paper explores the whole chain of valuation needed in order to produce a hierarchical ordinal ranking of the candidates. By drawing attention to the distinction between what is being said and what is being done by the gatekeepers, a structural ambiguity is identified in the selection game: on the one hand, it is dependent on romantic notions of artistic uniqueness (originality, personality, authenticity) and on the other, it relies on the requirements of jurisdiction and equal assessment (numerical grading, standardized repertoire). The artistic doxa of jazz is constituted in opposition to two negative characters, either by framing the candidates as epigones - echoing the standard repertoire too closely - or framing them as heretics, considered as traitors the local interpretation of the standard.
\end{abstract}

Keywords: Jazz, Evaluation, Audition, Music education, Gatekeepers, Selection. 


\section{Introduction}

Over the twentieth century, jazz evolved from being perceived as disgraceful, commercial and popular to occupying a place among the most legitimate forms of cultural expression. This structural change in the position of jazz within music genre systems is identifiable across most of the western world (Hobsbawm, 1989; Faulkner and Becker, 2009; Whyton, 2010; Nicholson, 2005; Coulangeon, 2005; Arvidsson, 2012). Faulkner and Becker (2009) note that the early generations of jazz musicians learned to play music predominantly through informal performances and jam sessions at jazz clubs, piano bars and weddings, whereas contemporary musicians study in formal, institutionalized training programs. The gradual institutionalization of “jazz" can be seen as a case, where actors negotiate and struggle around a certain "standard" (Bourdieu, 2004). The advancement of jazz as a separate field of music production and the corresponding separation from other forms of entertainment (e.g. dancing, talking and drinking) relates to the strengthening power of the earlier jazz generation who currently hold prominent positions as teachers, critics and members of art committees.

For Bourdieu, the outcome of institutionalized entry-tests depends on the meeting of "two histories" (Bourdieu, 2004). On the one hand, there are the social and musical dispositions that the candidates bring to the audition, which supposedly condition their "improvisations" according to the uneven distribution of symbolic assets. On the other hand, there are the fieldspecific rules of entry. ${ }^{2}$ One characteristic feature of artistic fields that Bourdieu himself seem to have been particularly fascinated by was the non-formalized nature of their rules of entry (Bourdieu, 1996, p. 226). At the time when newcomers seek their way into autonomous fields of

\footnotetext{
${ }^{2}$ As the analysis of assets and dispositions in the audition space of applicants is published elsewhere (Nylander and Melldahl, forthcoming), this paper is limited to what Bourdieu saw as the field-specific "rules of entry", i.e. the tacit rules and regulations appropriated by the gatekeepers in order to produce selection.
} 
cultural production, the entry conditions are rarely straightforward, explicit or outspoken; rather they tend to be vaguely or scarcely defined. Bourdieu's favorite metaphor, when trying to characterize the permeability involved when seeking to enter an artistic field, is having "a sense of the game" (cf. Bourdieu, 1996, p. 290; Bourdieu and Wacquant, 2004, pp. 120-121).

Many great social scientists in the twentieth century - most notably Max Weber and Claude LevíStrauss - have remarked that music has religious pretensions. Leví-Strauss (1981) argued that music is the most prominent inheritor of the myths that religion has left behind when the western world moved into secularization, starting from the seventeenth century and onwards. Weber even singled out instrumental music as being especially inclined to becoming a modern day ersatz (replacement) to religious experiences and characterized the charismatic communities as operating with a "virtuoso religiosity" (Weber, 1998, pp. 343-344). According to Bourdieu, autonomous cultural fields develop more fully in the eve of modernism, and in and around 1880s, music became the ultimate "art of reference" in the symbolic revolution of the artistic fields and came to purify poetry and literature as well as panting (Bourdieu, 1996, p. 391). In L'institutionnalisation de l'anomie (1987) Bourdieu compared the symbolic revolution of modern art to the religious revolutions, a parallel further accentuated by the introduction of sociological concepts such as that of doxa.

According to a recent definition by Gisèle Sapiro, Bourdieu's concept of cultural fields is meant to designate "the functioning of social spaces that have their own rules and within which the agents compete around specific issues" (Sapiro, 2010, p. xi). As later pointed out by Sapiro (2013), the proliferation of institutions of artistic consecration is one of the essential components in the autonomization of a cultural field as different agents then set out to compete about the legitimate definitions - and accompanied career positions - of what is now considered a specific art form. Today, the selection procedures leading up to a career in jazz typically involves educational 
institutions such as conservatories, institutes, colleges, programs or clinics. With the embeddedness of jazz in educational institutions, admission into prestigious educational sites is arguably becoming more and more important for aspiring musicians. ${ }^{3}$ The procedure that determines the question of access and helps reconstitute the rules of artistic entry in jazz is that of music auditions.

Bourdieu and researchers working in his tradition have shown empirically that in early selection processes, candidates are typically tested out on specific qualities cherished within the social field that they aspire towards (Bourdieu and Boltanski, 1981; Bourdieu, 1996; Menger, 1999; Royseng et al, 2007; Palme et al, 2012, Börjesson et. al., forthcoming). What is less clear from previous research within the Bourdieusian tradition, however, is how the selection processes to these fields are produced in situ. In order to address the practice of jazz-gatekeeping in greater detail I will, apart from Bourdieu's work, draw on work within French pragmatism and economical sociology, in particular Boltanski and Thévenot's (2006) typology on different "regimes of worth" and Karpik's (2010) conceptualization of “judgment devices” for assessing quality in markets with a high degree of uncertainty.

\section{The problem}

The topic of this paper concerns how gatekeepers within jazz education go-about to select their heirs. What does, for instance, this overarching process of jazz institutionalization mean for artistic selection? What are the practices of artistic valuation and evaluation in jazz music auditioning? How can the rather composite and opaque expression of sounds be converted into a final ordinal ranking?

Methodologically, observations and interviews with gatekeepers of two prestigious institutions in

\footnotetext{
${ }^{3}$ For general sociological accounts on the importance of college admission, see Palme, 2008; Stevens, 2009;
} Bourdieu, 1998; Cookson and Persell, 1985. 
Swedish jazz education were carried out. In addition, the analyses also relied on recordings of music, discussions and deliberations as they unfolded in audition rooms. Conceptually, an analytical distinction is drawn between what Schatzki (2012) refers to as the social practices of saying and doing. Making a distinction between sayings and doings allows the relationships and tensions between the practice of playing together, discussing and judging these performances to surface. The findings will eventually be related to the concept of an artistic doxa, a concept Bourdieu used to designate the collective and taken-for-granted beliefs of any particular field (Bourdieu, 1996, pp. 185ff; Bourdieu and Wacquant, 2004, p. 98).

\section{Earlier research}

The literature on gatekeeping and valuation in artistic fields is vast and growing. Here, I will limit my review to studies that relate to the cultural selection of gatekeepers. Also of interest are studies on musicians and their vocational careers, particularly those related to jazz. From its original formulation by Kurt Lewin (1947a; 1947b) the concept of "gatekeeper" has been used extensively to analyze processes of evaluation and selection within the arts and cultural fields. The simple and elegant idea of Lewin (1947b) was that the study of entry logics (frontiers) could reveal the modus operandi of social fields. Gatekeepers are thus particularly interesting agents to scrutinize as they control the social and aesthetic influx and thus the value associated with the institution or field of practice (Bourdieu and Wacquant, 2004). ${ }^{4}$ Since Lewin's publication, gatekeeping has been studied widely within the various fields of cultural sociology spanning the music industries (cf. Hirsch, 1973; Becker, 1982; Foster et al, 2011) to the classification of art in exhibitions (cf. White and White, 1965; Bystryn, 1978; Greenfeld, 1988; Zolberg, 1995), in the social fabrication of news and news-worthiness (cf. Manning White, 1950; Franssen and Kuipers, 2013; Whitney and Becker, 1982), as well as within peer-review and scientific evaluation itself (cf.

\footnotetext{
${ }^{4}$ Bourdieu acknowledged Lewin's work, alongside that of Weber and Cassirer, as paving the way to his own model of cultural fields and having laid the foundations of a relational thought in the social sciences more generally (Bourdieu and Wacquant, 2004, p. 97; Broady, 1995, p. 196).
} 
Janssen, 1997; Lamont and Huutoniemi, 2011). Apart from the influential work of Bourdieu, it is also possible to identify other alternative models of addressing the question of gatekeeping within cultural spheres theoretically - most notably through the work of Hirsch (1972) and Becker $(1982) .^{5}$

In Howard Becker's classical work Art Worlds (1982, pp. 40ff, 242) the creation of artistic conventions is portrayed as an interplay between innovation and the established tradition in which gatekeepers have the crucial role of shaping where the rules of the convention should be placed. According to Becker, innovators in music are a particularly rare specimen, something he goes on to accentuate by dubbing them as cultural "mavericks". Faulkner studies musicians in the Hollywood film industry (Faulkner, 1983; Faulkner and Anderson, 1987) and finds that collaborations and networks in the early parts of an artistic career - in his case, at a time when composers are trying to establish themselves as "a name" among the movie-makers - are likely to follow the cultural producers onwards, conditioning opportunities for future success. In their jointly written book "Do you know..." Faulkner and Becker (2009) writes about the collective customs of jazz in terms of an unfolding "repertoire-in-action", focusing particularly on what it takes to "jamming" together successfully. By a "repertoire-in-action" they mean an open-ended process that is constantly being "made and remade as people acquire, exchange, learn and teach the relevant elements" (Faulkner and Becker, 2009, p. 194). ${ }^{6}$

Research on valuation and evaluation of artistic practices is another relevant research field to this study. In the aftermath of Bourdieu's death, an extensive body of literature has evolved on the

\footnotetext{
${ }^{5}$ Cultural sociology related to "symbolic boundaries" lies close to the concept and function of gatekeeping, see particularly the anthology by Lamont and Fournier (eds.) (1993) and Lamont and Molnár (2002), for a more recent review. Another more extensive review on the theory and literature of gatekeeping - with an emphasis on research carried out within communication and media research - has been written by Shoemaker and Vos (2009).

${ }^{6}$ The micro-processes involved in successful jazz performances is elaborated more thoroughly by Faulkner and Becker (2009); Monson (1996) in the analytical framework of symbolic interactionism and Sudnow (2001) in the spirit of phenomenology. See also Berliner (1994).
} 
topic of how value is fabricated and evaluated in different social settings. Two particularly influential works within what Lamont (2012) calls "the sociology of valuation and evaluation" have been carried out by Boltanski and Thévenot (2006) and Karpik (2010), both expanding the classical bourdieusian emphasis of value (as symbolically derived from economical, social, and cultural domains of capital) to embrace what they see as multiple "regimes of worth" (Boltanski and Thévenot) and "regimes of coordination" (Karpik). In stark contrast to Bourdieu, Boltanski and Thévenot (2006) do not embark on the ambitious task of relating their different "regimes" to a single societal whole. Instead, they argue for an open-ended multitude of "orders" in which the question of value is established through practical negotiations and conventional forms of legitimation-procedures. ${ }^{8}$ Perrenoud $(2003 ; 2007)$ previously started a discussion on how the "regimes of worth", as they were once characterized by Boltanski and Thévenot (2006), might come into play in the social formation of "ordinary musicians". Perrenoud (2003) argues that the formation of musicians is split between the strategy of "professionals" that focuses on the "competences" among a larger collective of musicians, and those that propel the more romantic discourse of artistic "uniqueness".

Karpik (2010) examines how the aggregation of value is produced in different markets for unique products, i.e. in environments with a particularly high degree of uncertainty regarding the question of value. He finds that the work of experts and different "judgment devices" play a crucial part in classifying and differentiating unique products. Towards the end of his book on "the market of singularities", Karpik (2010) explicitly address the tensions and transformations of quality judgements, and expresses a fear of the possible "de-singularization of qualities" through overarching societal processes of standardization, marketization and bureaucratization, especially

\footnotetext{
7 The original French publications of Boltanski and Thévenot and Karpik were available well before Bourdieu's death, but their research was translated into English more recently and thus gained wider international recognition.

${ }^{8}$ Heilbron (2001) argues that this difference amounts to the stronger Durkheimian legacy in Bourdieu's work, something that is considered suspiciously "holistic" among many pragmatists and scholars working within the theoretical frames of the "economy of conventions".
} 
so in relation to music. The valuation of artistic practice through an audition can, following Karpik (2010), be seen as a "judgment device" to reach collegial agreement regarding the question of quality under the situation of uncertainty.

\section{The setting}

Jazz education in Sweden is offered in many different kinds of institutions: a number of uppersecondary schools (gymnasium) have jazz-oriented streams. Jazz can be studied in 15 different programs within folk high schools and it is an often-selected specialization in the Music Conservatories. This article is based on two weeks of observations, recordings and interviews at two folk high schools in Sweden, Big Baker (henceforth BB) and Eight Miles High (EMH). A folk high school is a Scandinavian educational institution typically characterized by its relative independence from the state. Music programs at folk high schools occur at an intermediate stage in the trajectory towards more professional music practice, roughly amounting to a 'junior college' level, i.e. before entering higher education (conservatory) and after finishing compulsory education. ${ }^{9}$

The relative abundance of possibilities of jazz enculturation and jazz institutionalization is related to transformations in the educational system as a whole. In the case of Sweden, Börjesson (2012) has shown how the last 20 years of morphological changes in the educational landscape following reforms of decentralization and marketization - has unintentionally resulted in enhanced artistic rivalry for the most established institutions of artistic consecration. Börjesson (2012) argues that the "exclusivity" of higher art education grows as the number of pretenders

\footnotetext{
${ }^{9}$ To give a very brief historical background of these educational institutions, the folk high schools first emerged in Denmark during the mid-nineteenth century to provide post-elementary education for farmers. Since the 1950s, the folk high school has established a role in art education in Sweden, especially in relation to music (Larsson, 2012). The number of programs available for young musicians aiming for a career within Swedish improvisatory music has expanded during the second half of the twentieth century. The expansion of Swedish music education has both taken the form of independently established 'study circles', as well as in post-secondary levels of institutionalized music education (Nylander, 2010).
} 
increases. Sweden has had a long history of producing and exporting musicians. In an international comparison, Nicholson (2005) has identified Scandinavian and Swedish jazz as an especially vibrant scene, something that he connects to the welfare states' generous cultural subsidies and the tradition of free music education. What goes largely unnoticed from Nicholson's interesting discussion however is the key role education plays in the cultivation of emerging generations of musicians.

Out of the 15 folk high schools that offered long-term jazz music programs in 2010, the auditions studied here are among the most selective (Nylander, 2010). BB and EMH's strong position in the Swedish music education landscape is reflected in previous studies (ibid) as well as in the fact that all the interviewed gatekeepers (music teachers) are currently working part-time as freelance musicians, and all but one are themselves alumni. The positions that $B B$ and $E M H$ uphold in the field of Swedish music production, especially in relation to jazz, seem at least partly established by the successful trajectories of previous generations of students, many of whom have gone on to win music awards or work as musicians professionally. Consequently, these few available positions available at Big Baker and Eight Miles High promote a breeding ground for intense rivalry. Among the 300 to 500 candidates $^{10}$ who auditioned at each of the music programs in 2010 , only 20 were finally admitted.

\section{Research strategy}

This article forms an integral part of a larger project that builds on Bourdieu's theory and methods to address issues of cultural heredity and educational selection (Nylander, 2010; Nylander and Melldahl, forthcoming). This paper sets out to study the audition as a selection device to guard the field of jazz, and is seen as constituted by social practices (Bourdieu and

\footnotetext{
${ }^{10}$ The number of candidates who auditioned is stated approximately because any exact number would risk identification of the schools.
} 
Wacquant, 2004, pp. 11-15). Auditions are dramatic events in which the value of a vast number of candidates is determined in a few highly decisive musical performances. In what seems like a single moment, all the hours devoted to musical practice, training, and jamming with friends are suddenly evaluated at once. The principal analytical distinction of social practice that will be perused here is between sayings and doings (Schatzki, 2012; Khan and Jerolmack, 2013). What is said about the selection is predominantly analyzed through interviews and evaluatory deliberations; whereas what the gatekeepers do in order to objectify the quality of the performances and reach agreements will rely on field-observations and notes taken during the course of action. ${ }^{11}$

Pursuing an analytical distinction between "doings" and "sayings" has been done by Schatzki (2012) and Khan and Jerolmack (2013). Though it is not my intention to follow Schatzki's full ontology, there are many affirmatives between his philosophy of "bundles of action" and Bourdieu's praxeology, the most obvious one being the emphasis on practices and its interconnectivity (see also Schatzki et al (eds.), 2000). Khan and Jerolmack (2013) have argued that the methodological distinction between sayings and doings is particularly useful in ethnographic research as it helps us unravel the discrepancies between what people say they do and what they actually do, i.e. by focusing on incongruities rather then interconnection. Khan and Jerolmack (2013) exemplify this approach by contrasting the meritocratic discourse of elite education with the underlying material privileges that tend to condition successful educational careers.

Auditions can also be seen as what Ball (1984) and Larsson (1993) term initial encounters. Through detailed school ethnographies on initial encounters in Britain and Sweden, the outset of

\footnotetext{
11 To be more exact, the focus here is primarily on the doings of the gatekeepers (valuation and evaluation), and more indirectly on the practices of candidates, i.e. the performances.
} 
classroom interactions are unraveled when teachers and students meet for the first time and set their agendas. These authors argue - as did perhaps Lewin, Goffman and Bourdieu before them that in such meetings "the rules of the game" become particularly visible because it provides a chance to view conflicts between participants' expectations. These conflicts later become invisible, as routines are "negotiated". Auditions are structurally similar to these two case studies (Ball, 1984; Larsson, 1993) as it deals with the question of institutional matching between student (expectations) and the evaluation formed in the jury committee.

My time spent observing, interviewing and residing with teachers, students and candidates in the audition amounted to one week at each school. The data used in this paper is partly based on live-recordings and observations made from the inside the audition rooms in situ. Open-ended, semi-structured interviews conducted with gatekeepers are another important source of information. While all of the gatekeepers were invited to participate as informants in the study, only half of the senior members of the gatekeeping staff at the two schools were interviewed (six of 12 , three from each school). However, the interview sample does represent all the instruments of the different juries in jazz (i.e. piano, voice, bass, drums, trumpet/saxophone/trombone, and guitar). ${ }^{12}$ All in all, the data used for the analysis in this paper consists of two weeks of fieldobservations, two full days of music and jury recordings inside the audition rooms ${ }^{13}$, six longer semi-structured interviews with gatekeepers, as well as fieldnotes and photographs from the sites of observation. The interviews with the gatekeepers lasted between 40 minutes and 1.5 hours each, both the interview material and the discussions of the jury members in situ were carried out

\footnotetext{
12 Obviously, there is no possibility of comparing data from the jury members that consented to be interviewed with the ones who did not want to participate. More semi-structured interviews, in total 20 of them, were conducted with candidates and the current students of $B B$ and $E M H$. Among these, only the interviews with the informants that partook in the jury discussions were included in this presentation.

${ }^{13}$ The reason why these recordings were limited to just two full days, and do not cover the whole period of the oneweek auditions at each school, is because recording the auditions require approval from all of the participating agents (candidates, juries, comping band, principal, etc.), something that was hard to arrange. Indeed, one of the toughest challenges of doing fieldwork in prestigious art venues is gaining access. In this case, access was facilitated by music acquaintances and friends that were alumni and who operated as brokers to the gatekeepers.
} 
in Swedish language and transcribed as such before being translated into English. ${ }^{14}$ The material was then coded in relation to the underlying hierarchies verbalized by the gatekeepers and three themes identified: (i) the rule-following of rhythm, melody and harmony; (ii)to play the standard and to play with the standard; and (iii) the artistic personality and perceived originality of the performance. These thematic sayings were also compared to the notes on what the gatekeepers were doing, thus bringing certain tensions in the audition between artistic valorization and institutional evaluation to the fore.

\section{Findings}

"Jazz. is a very big word."

- Leonard Bernstein, The World of Jazz (1955)

The findings will now be presented along the three major themes that relate to the overarching research problem. In particular, this section illustrates a temporal chain of artistic valuation and evaluation - from the set up of the standard and composite expression of sounds, to the final grading and ordinal ranking. The presentation will also proceed in a hierarchical order of artistic valuation as expressed by the gatekeepers, starting out with what they tend to see as more basic qualities (following rhythm, melody and harmony), before moving on to more abstract, opaque and abstruse notions of quality (personality, presence, artistic originality).

In both schools, Eight Miles High and Big Baker, each candidate is primarily expected to play two songs at the audition. One song must be chosen from a fixed repertoire of jazz standards -

\footnotetext{
${ }^{14}$ Because auditions are sensitive events, I have found it necessary to take several measures to ensure the anonymity of my informants, e.g. concealing the participants' exact areas of instrumental expertise. This prevents me from providing detailed discussions of the particularities of the instrument expertise, and might be considered at risk of over-generalizing my results as I emphasize the general themes of musical judgment. See Monson (1996) and Gibson (2010) for arguments where the instrumental differences and soloist/rhythm divisions in jazz ensembles are emphasized.

15 “The World of Jazz" was part of a television series called Omnibus featuring music lectures by Leonard Bernstein. This particular episode was first aired in the US on CBS on 16 October 1955.
} 
including classics such as Footprints, Lady Bird, Softly as in a Morning Sunrise, I Remember You and, for vocalists, My Romance and Angel Eyes - while the other song may be freely chosen by the auditioning candidate. To assist the candidates in the test, a comping band is organized from freshmen and sophomores currently enrolled in the jazz program. Other enrolled students assist the main instrument teacher in the jury. The teacher, who evidently leads the jury work, often begins by asking the novices about their current work or study, before asking them to explain their plans for the particular performance. Here is one example of what was said prior to the performance:

Comp_Bass player: What are we playing?

Candidate_Drums: I was thinking Footprints and Nardis, starting up with Nardis... To me the form is not of utmost importance but I was thinking of something along the lines of Theme-Solo-Solo-Theme... We can start off with a saxophone solo... and then I can have a drum solo... There I was thinking if you guys could play the first two chords openly, so we go "duom, duom, duom... duom, duom, duom" like...

Comp_Bass player: Any particular bass-line there or...

Gatekeeper: You will make something up.

Candidate_Drums: Yes, something to a suitable degree inspired by Metal.

Gatekeeper: Hahaha! "Something to a suitable degree inspired by Metal.” Hahaha, you're funny!

Candidate_Drums: ... eh, I don't know why I am so terribly nervous. I have never been this nervous in my life!

When presenting their songs, the novices are expected to play the role of bandleader as they structure their chosen jazz standard, choose the themes, cue who should play the solo at what point in time. As seen in the quote, the candidate's ability to address and select from the jazz repertoire is valuated, and some initial sayings are needed, well before the performance per se. In this particular case the candidate is interested in fusing jazz with a genre that is not considered 
appropriate by the gatekeeper, i.e. heavy metal. ${ }^{16}$ In fact, the gatekeeper seems to understand the suggestion of merging Heavy Metal and Jazz as an entertaining joke, something that then appears to accentuate the candidate's inherent insecurity. The heterodoxy of the genre preferences of the particular candidate is nevertheless evidenced in practice, as s/he sets up a drum solo with an effort to fuse in some "blast-beats" (a repetitious sixteenth-note figure played at a very fast tempo) into the more familiar jazz convention and its canonic standards (here in the form of Wayne Shorter and Miles Davis compositions). Once the candidate and the comping band are done talking, valuation move to the more intrinsic aspects of the artistic performance, i.e. sounds and judgements that evolve from music practices.

\section{The rule-following of thythm, melody and harmony}

According to the interviews and live-recorded valuations, the gatekeepers valuate candidates' competency in terms of harmonic, rhythmic and melodic knowledge. However, these aspects tend to be portrayed as rather basic by the gatekeepers, and are often placed in contrast to more abstract spiritualistic notions. There seems to be a tendency among the gatekeepers to take these sonic properties of rhythm, melody and harmony somewhat for granted. Anna, who is an instrument teacher at BB and has a relatively successful career as a solo musician, is an exception to this observation. In my interview with her, she stated the following:

I can be very clear about this... What we look for is harmonic knowledge, rhythmic knowledge, melodic knowledge and personal expression. The last one being a little bit more abstract then the other ones. So harmony, melody and the rhythmic parts - that is really what we are after!

Anna is optimistic about explaining the criteria that determines the outcome of the audition. She says that it is about harmony, melody and the rhythmic "knowledge", something that is tested out in conventional ‘jam sessions’ (cf. Dempsey, 2008; Faulkner and Becker, 2009; Gibson, 2010). By describing jazz excellence in a clear, concrete manner, and concentrating the description to the

\footnotetext{
${ }^{16}$ For an influential study on the symbolic boundary work within music, in particular related to the exclusion of Heavy metal, see Bryson (1996).
} 
fundamentals of harmonic, melodic and rhythmic knowledge, Anna is stressing trainable skills and competences. However, Anna's description of the final critical dimension, that of "personal expression", refers to the more abstract and opaque dimension of the performance, indicating qualities that is not reducible to these properties. Other than Anna, most other interviewees were reluctant to reduce their aesthetic valuations to a restricted set of rules.

More frequently, the issue of selection and the cutting-edge "criteria", was addressed at great length and with a general sense of imponderability, ineffability or even mystery. The case of Anton could be illustrative of how more qualities than harmony, melody and the rhythmic "knowledge" can be said to be involved. Anton is a senior teacher at $B B$ and is responsible for one of the solo instruments. Summarizing the recent selection in the jury, he remarks:

As I recently told my student representatives in the jury, I normally think of musicality as some sort of talent... something like: "is there musicality here that we could develop?" The expression: "do you succeed in directing what you do so that it reaches us, the audience?" Technique: "how have they acquired the abilities... in a more... in a very physical sense..."And then improvisation and flow: "have they developed their phrases?" "Can they play by ear?" "Have they developed a pitch?"

Anton refers to a series of rule-following procedures that need to be acquired in order for the candidate to be considered. His aesthetical summery of artistic virtue is expressed as either/or alternatives: "Can they play by ear?" "Do you succeed in...?" These questions are both categorical and normative as they can be answered with "yes" or "no", "good" or "bad". Anton refers to some qualities that carry slightly different labels used by Anna, including "musicality", "improvisation" and "expression". "Musicality" seems to be a key quality according to Anton, something he understands as similar to natural talent: "Is there musicality here that we could develop?" Musicality is contrasted to technique that is described as a physical ability that one can "acquire" by training. 
This valorization of musicality, as opposed to acquired technique, exemplifies a more generalized rhetorical maneuver performed by the gatekeepers - consciously or unconsciously - that sets up an opposition between physical and trainable "competence" and the more sacrosanct notions of musicality and personal expression. What is evident, at least, if we take the gatekeepers sayings to be somewhat legit, is that although a successful performance relies on harmonic, rhythmic and harmonic knowledge, these rule-following procedures are rarely understood as sufficient for elite admission. Other qualities of the craft are considered much more decisive.

\section{To play the standard and to play with the standard}

One reason why the gatekeepers do not explicitly discuss the basic rule-following practices of rhythm, melody and harmony, it may be argued, is that they take it for granted and see no need to lecture on "the basics". In the excerpts above, the gatekeepers also refer to additional qualities such as musicality, personality and "playing-by ear". Among the most crucial doings on the candidates' part is the ability to elaborate on the harmonies and tempo of the standard in smooth compassionate collaborations with the comping band, and create something seemingly new out of it.

Here is an extract from the audition room discussions of the rhythmic jury at EMH in which the collaborative dynamics of time and picking up on 'cues' are evident (or rather missing):

Comp_Piano_player: Now I am really eager to hear what you think about him. I thought it was such a pity! Because if he would have it played out a bit more he would have it... $(\ldots)$

Gatekeeper: I think he had a nice sound, but a bit undefined and afloat. Time is an issue for many. They can't play it out clearly.

Jr. Gatekeeper: I thought he tried to do something a bit fuzzy, but that it was not at all fuzzy, it was only very very dark all the time. Like an evolving pulp.. 
Gatekeeper: Yeah, the thickness of it all... With long phrases like that - brooo'p - it ends up like a wall, just like you are saying. What one would want are variations in the texture. And it strikes me that there is very few (candidates) that really pick up what you are doing. Most of the time it is the same... They play something like a'hhhhh (monotonic illustration of a tonality gradually coming down). It seems like they are busy "holding it together". No one is really communicating. (Long Silence)

Jr Gatekeeer: ....so far?

Gatekeeper: So far.

Having just closed the door for a round of (e)valuatory talks, the rhythmic gatekeepers of Eight Miles High here embark on a short summary of a young guy who just played Windows by Chick Corea, and Autumn Leaves originally composed by the Hungarian folk musician József Kozma. Apart from stressing how the rhythmic instrumentalist needs to be able to pick up "cues" and elaborate on what the comping band is doing - virtues more commonly associated with jazz soloists (Monson, 1996) - we see how the audition at EMH is carried out in a very open and deliberative mode. At EMH, the discussions of quality did even, at times, cross the invisible boundary between the comping band and the jury, involving all individuals in the audition room (sans the researcher and the candidate that just left the audition room). EMH has a far more open and liberal approach to student participation and cross-instrumental judgments than BB.

However, this seemingly democratic and collegial system of sharing opinions, both vertically and horizontally, needs to be related to the institutionalized evaluation practice of EHM where candidates are evaluated in two distinct stages (as opposed to one stage at BB) - an arrangement that allows for more open procedures at the very outset, as the senior gatekeepers know that further (e)valuations await the best candidates. ${ }^{17}$

\footnotetext{
${ }^{17}$ Lamont and Huutoniemi (2011) have studied how scientific strategies of evaluation differ depending on if they are structured in one or two chamber evaluations, and the degree of multi-disciplinarity in the juries. Similarly, the twostage evaluation of Eight Miles High allows the jury to incorporate students in the initial stage of evaluation. The straightforward one-stage evaluation of Big Baker, on the other hand, requires more respect to the immediate impressions of instrument expertise, and fosters more cautionary discussions that centers on the judgment of the senior gatekeeper as an (ultimate) authority.
} 
Another extract that illustrates the importance of the interactions and dynamics that occur during the audition jam is identified in an interview with Per. On top of being a senior teacher at EMH, Per teaches at a Swedish conservatory. Per is rumored to possess a strong influence in the Swedish jazz community and determines who appears at certain festivals and receives government grants. In addition to still being active as a freelance musician, he is married to another well-known musician. When asked what he listens for at auditions, Per replied:

Per: Musicality of course! ... If that person communicates something to us... But, we also look upon the craft. We can judge whether they have good technique, if they have good rhythm, if they have good harmonic skills. We consider all that to be important too. Some are really talented; when they take stage they say: "it shall be played like this! [Per snaps his finger one time] and like this [snap (2), snap, snap (4)] and like this [snap (2), snap (3), snap (4)]. I am going to play this, and I want you guys to play that, that and that..."

I also observe how they function in the group, as in... some might run everyone else over and push things so strongly that no one gets any space... Well that's not so good.

Interviewer. So that is what you mean by musicality, then?

Per: Well, yeah, I mean if I become affected to some extent. Some people can play for sure, but you know... it's like "ahaaa". [Per move his shoulders up and down, calmly]. And some people, they really try to do something... I mean artistically...

During the interview, Per continually returns to the question of whether or not the candidates "do something". Listening to the audition performances that Per endorsed as the best, one can clearly hear candidates proving themselves capable by commenting on small discursive fragments of sound played by the comping band, what in the jazz literature is sometimes referred to as cues (cf. Monson, 1996; Berliner, 1994). This quality is all about noticing signals, developing phrases and elaborating the standard repertoire in accordance with tiny little markers made up over the course of the performance. As the standard repertoire is performed with the accompanying band, sounds emerge that Per valorize as true artistry. When referring to these successful candidates, Per snaps his fingers as if to recreate the sonic experience of a successful candidate, as opposed to a more mediocre one. The very precise snap of his fingers captured on the tape and carried 
out in the unmistaken rhythm of syncopation, exemplifies that this is how it should sound like, got it?

The observations and fieldnotes taken from inside Per's audition room included an interesting case where two student representatives on the jury reached opposing conclusions regarding the quality of a performance. This episode can be taken to illustrate how delicate the appropriation of the rules of jazz entry can be. The particular candidate, who had played a rather long and experimental composition, clearly aspired to play free-form jazz with vague connections to melodic structure. The performance greatly impressed one of the sophomores in the jury, who claimed that this was the sort of performance he "had been waiting for". This student valued the candidate's sophisticated "alteration of sparse and dense textures", which he believed should be appreciable to any musician "since Coltrane". However, the other student representative said that while he typically does not object to musicians who play "completely out", this performance did not impress him at all. According to this other student representative, this particular free-form performance could qualify as almost anything - why even call it jazz?

Apparently, it does not suffice to locate oneself within the jazz tradition more broadly for the performance to be valued and valorized, as it is the more fine-grained frontiers that are at stake in the practice of aesthetical classification among the gatekeepers. It could also be noted that the rare occasion of open disagreement among the junior jury members were caused by a performance of free-form jazz. This is perhaps not surprising because within this subgenre, not much is left of the most obvious rule-following procedures of harmony, melody and rhythm, the conventional use of structure, notion of key and so on. One student assumed a more conservative position with regards to rule-following, while the other wanted to abandon what he saw as outdated rules in our "post-Coltrane" era. The conflict was eventually settled by the senior musician Per who concluded by saying that, "There is more to it than that". During the 
succeeding coffee break, Per explained that he considered these disagreements of quality

assessment to be particularly useful. By engaging in these discussions, he said that the sophomore students learn to be more observant of the sound conventions and acquire a more developed sense of the open-endedness of the genre. ${ }^{18}$

Because the band consists of enrolled students who will use any opportunity to test the novices' skills, this musical encounter resembles a "can-you-match-us?" initiation ritual in which the novices strive to improvise on the standards with their potential peers. In the interview with Per he discusses the successful candidates (person), rather than only characterizing a situation where impersonal rules produce an individual decision. He also turns affectionate and makes frequent usage of gestures and shorthand expressions. According to Per, thematic and procedural confidence is decisive in the audition. "I am going to play this, and I want you guys to play that, that and that". Sudnow once labeled these path-finding procedures as the 'forward confidence' of jazz improvisation (Sudnow, 2001, pp. 92, 113). ${ }^{19}$ To make an artistic move or, as Per says, to “ $d o$ something", the candidates need both the know-how and a steady belief in themselves and their artistic ability.

However, as Per attests, this confidence should be balanced with the ability to follow new and unexpected leads. Temporary functioning as the bandleader does not mean that you can have your way altogether. In the performance of the standard repertoire, the candidates must be both confident and responsive. They must balance their own performance in tone and style with what the members of the comping band are up to, so as not to make moves at the expense of others. If the candidates make moves that are too aggressive and idiosyncratic, they are likely to be

\footnotetext{
${ }^{18}$ Yet, it should be evident that there is a fostering aspect at play here. As Per takes a stance between the two conflicting view-points of the students, here siding with the more "conservative" jazz-jazz denomination, he inevitably marks out where the appropriate line of delimination should be and who among the students he agrees with.

${ }^{19}$ For a case study where confidence and authenticity are studied as a "trick of the trade" among popular musicians, see Grazian (2004).
} 
considered egoistic and out-of-touch. If they do not promote their own sound or voice enough, they will fail due to a lack of artistic engagement. This is a delicate act of balancing between listening and leading - what Bourdieu calls "a practical sense of the game", a deciphering in the present of the different possibilities that future pathways hold (Bourdieu and Wacquant, 2004).

Consequently, it is not sufficient to say that these candidates attempt to follow rules. Rather, jazz demonstrates how following artistic rules means something else than showing oneself capable of devote mimicking of a standard.

\section{Epigones and Heretics}

As illustrated above, at the time when the gatekeepers distinguish between legitimate and illegitimate expressions, a boundary is formed between the candidates who are attuned to jazz conventions and those who try too assiduously to follow the rules, and those who depart too much from them. In the case when the candidates lean too heavily towards what Becker (1982) refers to as the "artistic convention", they display a mode of playing that is bound to appear as epigonic in elite school admission. This is the type of candidate that Per thought "could play for sure" but was anyhow considered as lame legions of the craft. From the live-recordings, it is notable how the rhythmic jury reasoned about the rarity of candidates who could both provide texture to their phrases, as well as pick up on the more subtle sonic communication that occurs as the jam progresses and interaction unfolds. The emphasis on not being epigonic, lame or undefined seems to withstand this artistic division of jazz labor, as in between soloists and the rhythm session. The bulk of gatekeeping utterances marking out the behavior of epigones suggest that this constitute the most common criteria of artistic rejection in jazz.

Yet, as we have also seen from the field-recordings and interviews, the candidates might as well fail due to the opposite reasons, i.e. because they depart too much from the tacit and uncodified 
rules of the artistic field. At the other extreme, then, there are those aspiring newcomers whom Bourdieu classified as beretics (Bourdieu, 1996, pp. 239ff, 253), those who are not considered fully attuned to the sounds and procedures that the gatekeepers identify as essential for their specific stylistic appropriation of the repertoire. From this research, one obvious case of heretic rulebreaking is the case of the free-form candidate. A second extreme case, evidenced by our own data, is the heterodox genre merge of fusing heavy metal "blast-beats" into a Wayne Shorter composition. ${ }^{20}$ We also hear reccurring statements about the pitfall of egoistic mannerism - s/he is "taking up to much space" or "driving everyone else over" and so on. Simply put, the heretic pretender must learn to pay a closer tribute to the local deployments of the jazz standard, or the activity in the comping band.

American scholars have described the strong emphasis on listening and the practical mastery of "turn-taking” as reflective of a "democratic ethos" of jazz (cf. Faulkner and Becker, 2009, p. 133). In the social setting of elite music auditioning, these customs are however far from evident. To start with, the candidates differ widely in their capacity to respond to the higher demands of the jazz repertoire. Less adept candidates are quickly identified, and the ensemble could easily become a rather rude group of mockers instead of playing its role as a "collegial" comping band. Further examples of such negative rites include an inexperienced candidate being forced to speed up in double tempo, and a series of cases where the comping band did not give of their best as they were under-stimulated by the candidates' initial moves.

\section{Saying Personality...}

The last and perhaps most opaque theme verbalized by the gatekeepers is the conceived originality and artistic personality manifested in the performance. As frequently observed, the

\footnotetext{
20 The irony in this is that many see "blast-beats" as actually originating within Jazz drumming and, much later, growing into a conventional drum practice of music genres such as Metal and Grindcore. Musicologists have mentioned the 1965 recording of "Holy Ghost" with prominent jazz drummer Tony Williams and "heretic" Saxophonist Albert Ayler as one of many possible origins.
} 
cherished person/performance is often put in contrast to the ubiquitous competences of technique. This section will elaborate on the final and most abstract quality of jazz performances: personality. Eventually, I will ask how the sayings on singularity and artistic uniqueness can coexist with the commensuration of the artistic performance in one and the same scoring matrix.

Apart from the statements and recordings featured so far, one of the interviews with sophomore student representative Jerker also illustrates the juxtaposition of mundane techniques and the spirituality of personalized improvisational mastery. Jerker appears to be a typical $B B$ student: he is a native to Sweden's capital, Stockholm, and entered post-compulsory schooling immediately after completing a prestigious music program of upper-secondary education in the old city center of Södermalm. ${ }^{21}$ Following his second round of judgments for the day, Jerker reflects on the difficulty of working in his instrument jury:

If someone has been working extremely hard and has developed very special technical skills, that could be something to be taken under consideration. I mean, that's cool. But in the end it is more about... the energy... or... I mean the expression...

Which feels a bit awful because it is as if we are judging their personality. What you decide here has to do with their own personal expressions and that is something you need to stop thinking about... Otherwise you start to feel bad. It's like [saying]: "Who is the best person?"

Jerker can be seen struggling to distinguish between aesthetics and ethics, between the individuals he meets outside the realm of music and the individuals who express themselves to him through music. By assuming, yet hesitating, to equate the value of the candidate with the quality of the performance according to the artistic ordination of you-are-what-you-play and you-play-what-you-are,

\footnotetext{
${ }^{21}$ Södermalm is a neighborhood in the city-center of Stockholm where there is a high density of what the French informally call "bobo" or bourgeois boheme, e.g. journalists, established artists, academics and other representatives of the cultural fraction of the elite and middle classes.
} 
Jerker's testimony reveals one of the pivotal components of the artistic doxa, namely the oscillation of value attributed to the person by their specific artistic performance. ${ }^{22}$

In the above quote, Jerker seems first to assume a complete identification of the player with the particular expression he hears manifested in the more abstract dimension of the musical performance. Yet, as the biography of the candidate inevitably needs to be reduced to the internal musical manifestation of worth, at least in the case of a relatively autonomous music audition, Jerker hesitates on the legitimacy of such aesthetical purism. Later on in the interview, this hesitation regarding the aesthetic valuation is explicitly oriented towards ethics, as Jerker says that even though he has been brought up in an environment where music is self-evident, he considers such a legacy as a rare and enabling force of "privilege". 23

The idea that technique can be acquired through practice, while personal expression is of a more ineffable or mysterious origin is not limited to sophomores; instead it is a central component of most gatekeepers' sayings. The valorization of artistic personality as expressed by Roger, a rhythm teacher who has been active in Big Baker's jazz music program for many years. Roger's sayings are another example of how comparisons between the profane skills of technique and sacrosanct notions of the artist's personality play out in auditions. At first, Roger states that there are "universal aspects" to the quality of the performances, such as time and rhythm. However, there are also more pure artistic dimensions:

It could be more interesting to pick someone that you feel has a special expression and doesn't really 'play straight'... even though they are not as skillful as the others on their instruments. It is anyhow possible that we prioritize that person, since what we are after

\footnotetext{
22 In her book on Von Gogh, Heinich (1996) laid out the grammar of this type of artistic charismatic fallacy in greater detail. The "slippage towards biography" is considered among the foundational myths in the romanticism of artists, as it emerged from the eve of modernism and onwards.

${ }^{23}$ The intense labor and inherited capital that Bourdieu (1996) argues is a misrecognized 'condition of possibility' when entering elite institutions in the arts is partly acknowledged as such by Jerker. However, this apparent built-in reflexivity of the social world does not necessarily invalidate Bourdieu. One could easily imagine that Jerker adheres to the doxic attitude of "inspirational personalities" as soon as he is put back into the audition room. Indeed, such an ideological "double bid" is not uncommon among "well-informed" musicians and cultural workers.
} 
is... You feel that here is something artistically interesting which can be further developed... (...)

That it feels genuine... that they believe in what they do... are grounded in their own expression... They all come here in various ways. Some can really play but you feel it's only got to do with displaying practical skills; they are not fully there in the expression, even though it sounds right. In others you feel a strong presence, an expression of being there... which is, if not authentic, at least a presence, some kind of personality.

Although Roger does not teach a solo instrument, he values the same idiosyncratic virtues of genuineness and personal expression as his colleagues who are soloists. To clarify his most cherished qualities, Roger considers the candidate who is merely "displaying practical skills" but has not fully developed the level of personal expression of "being there". "Being there" is the musical manifestation of personality, a quality that is, "if not authentic, at least a presence" according to Roger.

However, it is also possible to identify a slightly more realistic line of sayings in the interviews with one of the gatekeepers, in which having "it" during the audition depends on both the rule-following procedures of harmony, rhythm and melody (so often associated with technique and "mere" practical skill) and the qualities that are considered more decisive, e.g. the ability to answer up on "cues" or being grounded in one's own "expression". Returning to Anton, we hear a realistic summary of the art of artistic judgment along these lines:

In the end you tend to pick the ones, how should I put it... the ones that take us aback... In the end these are the ones we pick, no matter what. The ones that really move us... but normally you would need all these tools and qualities in order to reach it... that includes technique, knowledge, expression and... everything!

Anton sums up the question of selection by saying that the candidate requires all the qualities he has mentioned to satisfy his understanding of the "it" of jazz mastery. To reach the point at which the jury is taken aback by the performance, the candidates appear to be required to prove their ability to follow the rules of the repertoire and, at best, use these for expressing themselves 
in what is considered a personalized way. According to Anton, the candidates who master their instrument fully also have the best chance to do something in relation to the repertoire that ultimately "moves" the gatekeepers and transcend the rules in the right way. ${ }^{24}$

\section{... Doing Numbers.}

The emotional intensities, verbal interjections and the many references to artistic personalities evident in the gatekeepers' sayings need to be compared to the evaluatory procedures or doings that they deploy while the candidates' play. In the case of an audition, several techniques are used in order to reach an agreement, produce and justify social selection (Boltanski and Thévenot, 2006; Karpik, 2010). Among the more curious means by which the gatekeepers operationalized the audition, there is numerical grading and the commensuration of the music performances into a fixed scoring matrix. For the gatekeepers, the standard songs used in the audition - Footprints, Lady Bird, Autumn Leaves and so on - also work as a familiar soundtrack against which artistic virtues of personality and idiosyncratic improvisatory charm can be identified and evaluated more easily. Over the course of evaluating the candidates, the gatekeepers translate their spontaneous judgements of quality into two different kinds of scoring matrixes, depending on the routines of the institution. The final outcome of the audition thus depends on a kind of semiquantity ${ }^{25}$ marked on a scale that ranges from 1 to 10 at $E M H$, and 1 to 100 at $B B$. A numerical grading lower that 6 at $\mathrm{EMH}$ or 70 and below at $\mathrm{BB}$, typically means that the candidate has no chance of entering the institution. When asked about the relationship between aesthetic classification and numerical

\footnotetext{
${ }^{24}$ From Nylander and Melldahl's (forthcoming) quantitative analysis, we will see that such "personality" is rarely recognized when candidates come with a general scarcity of inherited and acquired music resources. In total, 13 out of the 16 individuals who were successful in the EMH audition (and whom we studied in greater detail in this other publication) come from two groups that we classify as Insiders and Inheritors and had the most assets "to improvise with".

${ }^{25}$ Bunge (2012) suggests that a semiquantity is a numeral (a number name) rather then a plain or additive number. Though Bunge is known as an orthodox realist of science, he notes that a "semiquantity may consort with quantities and it may stimulate the formation of the corresponding magnitude" (Bunge, 2012, p. 72). For a historical analysis on the emergence of pseudoquantities in contemporary capitalist economies that contrast quantity and quality, see Liedman (2013). On the emergence of "sociology of quantification", see Espeland and Stevens (2008). Another influential account, trying to embrace the continuum between judgment and calculation (qualqulation), is outlined by Callon and Muniesa (2005).
} 
ordering of the performances to a fixed scoring matrix, the gatekeepers comment that the latter is sometimes a tricky task. According to Roger for instance:

The top is rarely a problem. They are distinguishable, immediately. But it is rare that the top is filled up completely. Many of them end up in the range there in-between $5-7 \ldots$ So if there are a lot of candidates - like this year on guitar - our job can be extremely difficult. Sometimes. Cause it ends up being about "what quality do I want to prioritize?" Someone has a more pronounced expression, someone else has better technique; it can also become a matter of stylistic preferences.

Roger points out the need to prioritize between conflicting notions of quality, something that is a shared experience among the gatekeeping community. For instance, one of the piano teacher dwells on this topic by comparing a young pianist who plays beautifully but lacks the particular “craftsmanship of jazz" (jazzhantverket), with another candidate who knows this specific "language of tonality" (tonspråket) yet plays utterly boring. Both gatekeepers representing soloist instruments and rhythm section assert that their judgements evolve out of the practice of prioritization, and include an inevitable element of aesthetical compromise (Karpik, 2010, pp. 117ff). But how are we to understand the evaluation strategy of ordering these relative numbers, against the backdrop of what the gatekeepers say about these performances?

Whereas grading procedures make comparisons across time and styles of performances possible through a ordinal standardization of performances along a fixed set of numbers, they also represent a kind of generalization that is in tension with the aesthetic inclination of treating every musical performance as a singular and unique event. Yet, without standardizing the music performances into these numbers, the gatekeepers would probably find it difficult to hierarchize the performances due to the sizeable number of candidates arriving at the audition and the spread of aesthetical expression they come to represent. Without any objectifying record of what has been happening within the audition rooms, the gatekeepers and schools can also be 
questioned on the bases of other "regimes" of justification, such as selection rationalities based on political or pedagogical primacy (cf. Boltanski and Thévenot, 2006).

By translating their aesthetical judgments into fixed numerical scores, the gatekeeping community can compare and keep track of each performance in relation to the rest. As some of the gatekeepers kept the score of last year's auditions open in excel sheets on their laptops, returning candidates could often face evaluations based on their relative "progress" from previous entry tests, apart from the scores of the other candidates. This indicate that time is a crucial factor here, not only in musicological terms.

Yet, against the backdrop of what is being said about the performances, the wide use of numeral grading and semi-quantification is a curious practice of artistic evaluation. The discussion of the audition presented so far includes in-depth descriptions of the doings and sayings of artistic gatekeeping in jazz. I will now conclude by further elaborating on these two interrelated practices of the audition: first, by addressing the audition as a procedure to hand down tacit forms of connoisseur knowledge; and, secondly, by focusing on the inherent tensions, paradoxes and pitfalls of artistic auditions.

\section{Discussion: The art of sound judgments}

"It is as though you needed some criterion, namely the clicking, to know the right thing has happened." - Wittgenstein, 1966, III, $\$ 2$

Auditions constitute one of the rare occasions in an educational trajectory in which everything that a student has learned, experienced and diligently practiced is evaluated at once, in one single entry test. Studying auditions means intervening at a decisive moment in the students' educational careers. From the time the performance begins, there is no hiding place, no turning back. As the 
performance evolves, the candidates must act according to what they believe is correct and fall back on muscular memories and ways of moving that they have acquired through previous practice. The senior instrument teachers interviewed frequently claimed to be able to distinguish a candidate's potential within the first few seconds of an audition performance. One bass teacher even claimed to be able to predict the outcome of the event on the basis of how the candidates carry their instruments! Because the jury members are so well acquainted with both "the original" jazz standards and the fairly established ways of departing from it, these ranking systems only occasionally produce disagreements.

However, stark differences between the students' and teachers' degrees of exposure to the jazz tradition are apparent in the collected data. As musicians-to-be, the auditions become a site of training for the student gatekeepers, not only in jazz practice as such but also in the art of appreciation, i.e. the way you introduce, listen to, and talk about jazz performances with others. Therefore, students' participation in the juries might have less to do with democratic principles of collegiality (as one would perhaps expect from a folk high school in Sweden) than with the exposure to a wide range of musical cases. Per's authoritative statement, that one of the major benefits of adding sophomores to the jury at EMH is to prompt and cultivate their aesthetic judgments, supports such interpretation. During the course of the auditioning week, numerous performances - a few good and many not so good - were listened to, aesthetically classified, judged and numerically scored. Included in the work of aesthetic classification and ranking, sophomores become keener at determining what to listen for, how to listen for it and how to valorize and verbalize what they have heard. These aspects of judging other musicians' sound and technique and justifying those judgments are important in their continuing journey towards becoming a musician. 
As noted by Bourdieu in Rules of Art (1996, pp. 223-224) and, more recently, by Menger (1999), Royseng et al (2007) and Palme et al (2012), the institutions of preparatory art education tend to foster abilities and values related to the requirements and ideals of the artistic labor market to which these students aspire. In this case study, the inclusion of sophomore students in the jury provides a way to hand down connoisseur knowledge (Bourdieu, 2004, pp. 3, 7-38), as well as ordinate them the status that comes by functioning as a gatekeeper in their particular field and artistic denomination. Because the gatekeeping agents function as musical mentors for the admitted student, the audition could be seen as a vehicle for cultivating the "ears" of future jazz connoisseurs. What the design of auditions effectively tests is how attuned candidates are to the field-specific standards, as these are appropriated locally in the specific institution.

Returning to our analytical distinction between sayings and doings, it seems reasonable to remark on certain overarching tensions in the audition. On the one hand, the gatekeepers launched a series of romantic notions of artistic uniqueness (originality, personality, authenticity) and on the other, they seem to rely on the requirements of jurisdiction and equal assessment (numerical grading, standardized repertoire). The ethnographic usefulness of the analytical distinction between sayings and doings lies, partly, in the friction that manifests when comparing these two layers of social practice (see also Schatzki, 2012; Khan and Jerolmack, 2012). Auditions are a particularly pertinent venue to observe the incongruences between expectations and actual practice. By focusing on the procedures of action as well as what is being said, this analytical distinction also favors an interconnected view of social practice, where the whole chain of artistic valuation can be outlined, and different forms of valuation and evaluation related to one another. ${ }^{26}$

\footnotetext{
${ }^{26}$ An analysis of the practices of sayings and doing thus moves well beyond the inaudible textual fundamentalism so often encountered within mainstream forms of discourse analysis. To follow the terminology of Schatzki, such analyses should also pay attention to how sayings and doings are "bundled together" and not stop at a simplistic contrasts between what people say and what they do (cf. Khan and Jerolmack, 2012). On the ethnographic strategy of comparing and connecting interviews and observations, see also Becker and Geer (1957).
} 
Although the whole point of attending these auditions is to become recognized as a promising musician in-the-making and get the opportunity to develop these proficiencies further, the entrytalk of the gatekeepers is allied with the esoteric artistic hagiographies of charisma and individuality (Kris and Kurz, 1979). Jazz gatekeepers are not unique in overemphasizing the heroic and inspired personality it takes to qualify to their exclusive community. But in the case of music auditions, this charismatic fallacy is especially ironic as the entire point of the event is to seek artistic recognition by more experienced musicians. This wider framing of the audition also means that successful candidates stay far away from the performance of "mavericks" - the ones who Becker (1982) claims to be responsible for revitalizing artistic production.

Furthermore, we have seen how the test situation requires some standards of comparison to make selection a synchronized and "fair" game. Recall, for instance, the widespread use of standardized songs or the way the gatekeepers assessed the musician's sound using a fixed scoring matrix. Given the problem of keeping track of how the composite sounds of jazz performances correspond to the great number of candidates in the audition, such evaluation procedure is fully understandable. Yet, posed against the backdrop of what is being said about the performances, the use of semi-quantifiable grading routines is a somewhat curious practice. The paradox should be apparent as a performance can hardly be "unique" and scored as 8 at one and the same time. If the performance would be truly unique, the gatekeepers would hardly recognize it as such, no less reduce it to a plain number. On a more philosophical note, one might feel inclined to ask how a previously unrecognizable musical expression can become recognizable to them, if not based on previous experiences? And what sound can possibly emerge outside the sonic properties of rhythm, melody and harmony? 
Perrenoud (2003) notes a similar ambiguity in the formation of "the figure of the musician" when he writes that the principle tension among musicians is the one between a strategy of presenting one's self "as a competent class" and one that clings on to the romantic image of "artistic uniqueness". The evaluation of jazz in auditions congregate around a similar opposition of clear Weberian resemblance; on the one hand, practices that are allied with institutional rationality and competence-oriented assessment, and the charismatic discourse of artistic uniqueness on the other. With Boltanski and Thévenot's (2006) different regimes of worth in mind, ${ }^{27}$ one could consider the doings of evaluation - screening of familiar standard songs, numerically ranking the contesters - as oriented towards justification principles based on domestic and institutional forms of legitimization, whereas the sayings of the gatekeepers point in a different direction, drawing its rationality from the "inspirational" principle of worth so common among artistic fields.

The paradox of artistic valuation thus centers on an inherent tension between the valorization of artistic connoisseurs, transgressing the formal competence-based procedures, and the assessment procedures of standardized evaluation. In his mini-taxonomy of valuation, Vatin (2013) suggests a conceptual distinction between the valuation practices of valorization and evaluation. Valorization could, now applying Vatins (2013) formula, be taken as the more dynamic term of artistic appreciation whereas evaluation would be ascribed to the less aesthetically puristic practices, such as when the gatekeepers convert their aesthetical inclination of "sound judgements" to a relative scale and standardized outcome; i.e. the institutional side of testing.

According to Karpik (2010), the two overarching processes of establishing artistic selection is incommensurable insofar as the numerical assessment procedures are based on a pseudo-additive, logic of "calculativeness"; whereas jazz music is an artistic practice of singularity, something that

\footnotetext{
${ }^{27}$ As is probably well known by now, Boltanski and Thévenot (2006) outline an entire 'grammar' of justification by focusing on the conventional forms such action take in different social situations. They identify six 'orders of worth' (grandeur) to be particularly forceful ways of establishing equivalence and generality. These are: the inspired, the domestic, the industrial, the market, public opinion and the civic.
} 
exacerbates additive forms of quantification. As also pointed out by Karpik (2010, pp. 117ff), it is not necessary, however, to treat judgment as an antinomy to calculation altogether. From our data, we have seen examples of how the use of numerals can differ if the gatekeepers are addressing a candidate who "really moves" them or if the score is meant to merely differentiate among the mass performances. Rather, as Karpik (ibid, p. 41) proposes, these musical judgments seem to "ground the comparison of incommensurabilities", thus urging us back to the overarching structural conditions within which calculation occurs.

Artistic judgements and the rules that guard access to prestigious forms of art education are as we have seen never fixed or settled; rather they are gradually developed and need to be related to the artistic fields where they are cultivated, negotiated and appropriated locally (Bourdieu, 2004; 1996). Contrary to the type of transparent and profane value systems that dominate in society as a whole, proper artistic valuation seem to evade bureaucratic and political principles of justification in favor of the charismatic mythology of metaphors and ineffable notions of uniqueness and singularity.

As Karpik's (2010) recent work on the market of singularities clearly illustrates, the different ways that agreements are reached and judgments are formed, eventually go on to shape how the specific market of singularity will work - in our case, how jazz will sound and what we will mean by having "it". ${ }^{28}$ Though the results of these ethnographic explorations indicate that jazz is a highly privileged expression of individuality among the gatekeepers - an aspect that again needs to be related back to the historical formation of jazz as a relatively autonomous artistic field in the early twentieth century - the valuation processes that guard access to this field is certainly not

\footnotetext{
${ }^{28}$ Karpik (2010, p. 243) notes that the processes of standardization and de-qualification in the music industries are related to what he calls "the common-opinion regime" and the symbolic authority of charts.
} 
without tensions and contradictions. Even if jazz has undergone a process of institutionalization, its rules of entry seem to resist codification in the name of autonomy.

Following Bourdieu's (1996) lead on the dynamics of consecration to artistic fields, we have seen how candidates must not only subject themselves to the underlying rules in the audition - here manifested in the play of harmonies and in following the comping band's pace and tempo - but also display a more general ability of musical precognition or "feeling for the rules". Observations, interviews and live-recordings from my two weeks of auditions at Big Baker and Eight Miles High have shown that a subtle "play with the standard" - manifested as moves and distinctions made at the course of eight- or four-bar-turn-takings is setting the aesthetic jazz connoisseurship apart from other kinds of evaluation. The more decisive marks of artistic valuation as proposed by the gatekeepers of jazz included (but were not limited to) being able to respond to cues, adjusting to changes, accelerating or decelerating in tempo, playing behind or ahead of the beat, quoting canonic phrases and finding one's own phrase and texture..$^{29}$ Perhaps opaque and obtrusive to an untrained ear, these practices can in fact be likened to questions posed during other job interviews.

It is important to note here that according to Bourdieu's theory of cultural fields (1996), access to fields is dependent both on "the rules of entry" as they are deployed and appropriated by the gatekeepers guarding access to the field, and the social dispositions of the candidates and how they match the former. At the auditions, each candidate embodies and makes use of abilities and resources accumulated up to the point of examination, which is a dimension of the entry-test that will be presented elsewhere (Nylander and Melldahl, forthcoming). In this regard, Bourdieu's

\footnotetext{
${ }^{29}$ This presentation has not ventured into the musicology of these performances. In such analysis, the overarching tension identified in this sociological analysis of the audition - roughly oscillating between institutional testing and artistic individuality - would probably need to be related to a possible homology in relation to the musical elements of composition and improvisation. The musicology of jazz practice and its rather genre-specific argot has been described more thoroughly by Berliner (1994).
} 
approach departs from takes on jazz practices as it has derived in cultural sociology rooted in Goffmanian interactionism and Wittgensteinian contextualizations (cf. Faulkner and Becker, 2009; Becker, 2000; Monson, 1996; Gibson, 2010; Dempsey, 2008) - in that it seeks to anchor the "language games" in the deeper dispositional habitus that each candidate carries to the performance. When the jury finally distinguishes between legitimate and illegitimate expressions or, what amounts to the same thing: if the candidates are attuned to the conventions or not these aesthetic and social selection games merge.

Following Bourdieu's reading (1996, pp. 297-298) of Wittgenstein (1966), one could argue that the language game of the gatekeepers is not as dependent on the precise sayings (descriptions of mastery or by unified criteria of evaluation) as much as on the function these appreciating notions have within the specific test-situation and how the gatekeepers, in return, situate these performances within the wider realm of the artistic field of jazz. Though there certainly are ways to prepare for the entry-test-situation, jamming your way through the entry test also means being led in quite unexpected sonic directions; the successful candidate will thus inevitably prove capable by responding to the open-endedness of jazz as a repertoire. The rare conflict between the two students regarding "post-Coltrane" free-form jazz demonstrates that differing interpretations of the rules can prove incompatible, as the evaluation criteria of jazz quality is open-ended and pluralistic. The way the gatekeepers reached agreements - and cultivated the students to do so - is facilitated by the relative proximity of the lifestyle and taste-preferences of those mastering the jury of Big Baker and Eight Miles High (Bourdieu's habitus), but also seem to rely on what Karpik (2010) calls "judgment devices" such as the establishment of a canon (the standard of the standards), the use of technology (data, software) and the ordinal ranking of performances into semiquantities. ${ }^{30}$

\footnotetext{
${ }^{30}$ Boltanski (2011) argues that the kind of tensions identified here, between the realms of semantics (sayings) and pragmatics (doings), points towards a more general "hermeneutical contradiction". Boltanski asserts that "a world where pragmatics always win over semantics is difficult to conceive, because it would generate an infinite
} 


\section{Concluding remarks: Towards a doxology of jazz}

The overarching argument of this article has been that the romantic discourses of jazz entry, as free from all structural constraints and as an expression of idiosyncratic personalities is more sociologically understandable as a doxic principle of artistic valuation. However, these findings suggest that the doxa of jazz is constructed in relation to two excluded characters: the heretics and the epigones, a modification of Bourdieu's original framing of orthodoxy versus heterodoxy. ${ }^{31}$ The beretic rule-transgressions that Bourdieu himself identified is one possible ground of artistic rejection according to the gatekeepers of jazz, potentially blasphemous to the local appropriation of the repertoire. The heretics of the audition thus run the risk of being denounced as they have distanced themselves too much from the tacit code-of-conduct, dictating the rules of entry at the specific point where they seek to enter.

More commonly, however, the candidates were seen to mimic the jazz standard too closely.

The analysis suggested that this was an artistic failure of the epigones - an aspiring musician who, instead of proving themselves capable of keeping up to the higher demands of jazz mastery such as responding to discursive fragments during the performance ("cues"), playing slightly behind or in front of the beat and providing a sense of personality to the expression, "play the standard in a standard way". Here the selection of jazz heirs is hindered by candidates echoing the jazz standard too closely, often in rather devote servitude to well-known themes and ways-to-goabout. Another somewhat paradoxical conclusion is, that the institutional ethos of jazz is antiinstitutional at its core.

\footnotetext{
fragmentation of significations, a reality entirely subject to a semantics stabilized from institutional positions would also be one where action either become impossible, or was condemned to be performed by serving the links that relate it to language or even any other type of semiotics” (Boltanski, 2011, pp. 91-92).

${ }^{31}$ However, this dual characterization of the pitfall of the epigones and heretics has some affinities to Zolberg's (1995) categorization of high-end art collectors in the US.
} 
The oppositions launched between mundane mass technical skills to the more charismatic notions of individual excellence of the selected few, and the equation of the biography ("whoyou-are") and the artistic expression ("how-you-play"), as well as the ineffability of the gatekeepers to specify a finalizing criteria of jazz mastery, all ought to be related back to the historical roots of artistic fields as a processor of religious belief-systems (Kris and Kurtz 1979; Bourdieu, 1996; Sapiro, 2007).

At its most general we have argued, similarly, that the inherent paradoxes of valuation in jazz operate in a Weberian dialectic between the institutional need to formalize certain standards (where all candidates can compete with each other on equal terms), and a treatment of jazz as a true artistic performance where the expression of an inner state of mind, an individuality, is pronounced. Improvisatory romanticism can perhaps, then, be situated as lingering on a fine line separating rule-following from its inevitable correlative - that of rule-breaking. 


\section{About the Author}

Erik Nylander is a PhD-student in Education at Linköping University, Sweden. His ongoing thesis is concerned with the enculturation of musicians, in particular their career trajectories and the selection processes within Swedish jazz. Nylander is also the co-editor of the open access journal Confero: Essays on Education, Philosophy and Politics and an affiliated collaborator with the research unit SEC at Uppsala University.

\section{References}

Arvidsson, A. (2012) Jazzens väg till svenskt kulturliv:: Sala: Gidlunds förlag.

Ball, S. (1984) Initial encounters in the classroom and the process of establishment. In: M. Hammersley, and P. Woods (eds.) Life in school. Milton Keynes: Oxford University Press, pp, $108-121$.

Becker, H. (1982) Art Worlds. Berkeley: University of California Press.

Becker, H. (2000) The Etiquette of Improvisation. Mind, Culture, and Activity 7(3): 171-176

Becker, H. S., and Geer, B. (1957) Participant observation and interviewing: A comparison. Human Organization 16(3): 28-32.

Berliner, P. (1994) Thinking in Jazæ: the infinite art of improvisation. Chicago: Chicago University Press.

Boltanski, L. (2011) On Critique A sociology of emancipation. Oxford: Polity Press.

Boltanski, L., and Thévenot, L. (2006) On justification: Economies of worth. Princeton, NJ: Princeton University Press.

Bourdieu, P. (1987) L'institutionnalisation de l'anomie. Cabiers du Musée national d'art moderne 1920: pp. 6-19

Bourdieu, P. (1996) The Rules of Art. Cambridge: Polity Press.

Bourdieu, P. (1998) The state nobility: Elite schools in the field of power. Stanford: Stanford University Press.

Bourdieu, P. (2004) Science of science and reflexivity. Chicago: University of Chicago Press.

Bourdieu, P. and Boltanski, L. (1981) The educational system and the economy: Titles and jobs. In: C. Lemart (ed.) French sociology: rupture and renewal since 1968. New York: Colombia University Press, pp. 141-51.

Bourdieu, P. and Wacquant L. (2004) An invitation to reflexive sociology. Cambridge: Polity Press. 
Börjesson, M. (2012) Konstnärliga utbildningar och produktion av exklusivitet. In: M.

Gustavsson, M. Börjesson, and M. Edling (eds.) Konstens omvända ekonomi: Tillgångar inom utbildningar och fält, 1938-2008. Göteborg: Daidalos, pp. 39-66.

Börjesson, M, Palme M. Lidegran, I., Le Roux, B. Broady D. (forthcoming) "Cultural and FieldSpecific Capital among Students in the Elite Segment of Swedish Higher Education". Poetics, In press.

Broady, D. (1995) Sociologi och epistemologi: om Pierre Bourdieus författarskap och den bistoriska epistemologin. Stockholm: HLS.

Bryson, B. (1996) "Anything But Heavy Metal": Symbolic Exclusion and Musical Dislikes. American Sociological Review 61 (5): 884-899.

Bunge, M. (2012) The sociology-philosophy connection. New Jersey: Transaction Publishers.

Bystryn, M. (1978) Art Galleries as Gatekeepers: The Case of the Abstract Expressionists. Social Research 45 (2): 390-408.

Callon, M. and Muniesa, F. (2005) Peripheral Vision Economic Markets as Calculative Collective Devices. Organization studies 26(8): 1229-1250.

Coulangeon, P. (2005) Social stratification of musical tastes: questioning the cultural legitimacy model. Revue Francaise de Sociologie 46: 123-154.

Cookson, P. W. Jr. and Persell, C. H. (1985) Preparing For Power: America's Elite Boarding Schools. New York: Basic Books.

Dempsey, N. (2008) Hook-Ups and Train Wrecks: contextual parameters and the coordination of jazz interactions. Symbolic Interaction 31: 57-75

Espeland, W. N., and Stevens, M. L (2008) A sociology of quantification. European Journal of Sociology 49(3): 401-436.

Faulkner, R. (1983) Credits and Craft Production: Freelance Social Organization in the Hollywood Film Industry. Symbolic Interaction 6: 111-123.

Faulkner R. and Anderson, A. (1987) Short-Term Projects and Emergent Careers: Evidence from Hollywood. American Journal of Sociology 92 (4): 879-909.

Faulkner, R. and Becker, H. (2009) “Do you know... ?”: The jazz repertoire in action. Chicago: University of Chicago Press.

Foster, P., Borgatti, S. and Jones, C. (2011) Gatekeeper search and selection strategies: relational and network governance in a cultural market. Poetics 39: 247-265.

Franssen, T., and Kuipers, G. (2013) Coping with uncertainty, abundance and strife: Decisionmaking processes of Dutch acquisition editors in the global market for translations. Poetics 41(1): 48-74. 
Gibson. W. (2010) The group ethic in the improvising jazz ensemble: a symbolic interactionist analysis of music, identity, and social context. Studies in Symbolic Interaction 35: 11-28.

Grazian, D. (2004) The production of popular music as a confidence game: The case of the Chicago blues. Qualitative Sociology 27(2): 137-158.

Greenfeld, L. (1988) Professional ideologies and patterns of "gatekeeping": Evaluation and judgment within two art worlds. Social Forces 66(4): 903-925.

Heinich, N. (1997) The glory of Van Gogh: An anthropology of admiration. Princeton, NJ: Princeton University Press.

Heilbron, J. (2001) Economic sociology in France. European Societies 3(1): 41-67.

Hirsch, P. M. (1972) Processing fads and fashions: An organization-set analysis of cultural industry systems. American Journal of Sociology 77(4): 639-659.

Hirsch, P. M. (1973) The structure of the popular music industry: the filtering process by which records are preselected for public consumption. Ann Arbor, Mic: Institute for Social Research, The University of Michigan.

Hobsbawm, E. (1989) [1959] The Jazz Scene [First published under the name of Francis Newton]. London: The Guernsey Press.

Janssen, S. (1997) Reviewing as social practice: Institutional constraints on critics' attention for contemporary fiction. Poetics 24(5): 275-297.

Karpik, L. (2010) V aluing the unique: The economics of singularities. Princeton, NJ: Princeton University Press.

Khan, S. and Jerolmack, C. (2013) Saying Meritocracy and Doing Privilege. The Sociological Quarterly 54(1): 9-19.

Kris, E. and Kurz, O. (1979) Legend, myth, and magic in the image of the artist: An historical experiment. New Haven: Yale University Press.

Lamont, M. (2012) Toward a comparative sociology of valuation and evaluation. Annual Review of Sociology 38: 201-221.

Lamont, M. and Fournier, M. (eds.) (1993) Cultivating differences: Symbolic boundaries and the making of inequality. Chicago: University of Chicago Press.

Lamont, M. and Huutoniemi, K. (2011) Comparing customary rules of fairness: evaluative practices in various types of peer review panels. In: C. Camic, N. Gross and M. Lamont, M. (eds.) Social knowledge in the making. Chicago: University of Chicago Press, pp. 209-32.

Lamont, M. and Molnár, V. (2002) The Study of Boundaries Across the Social Sciences. Annual Review of Sociology 28: 167-195

Larsson, S. (1993) Initial encounters in formal adult education. Qualitative Studies in Education 6(1): 49-65. 
Larsson, S. (2012) "Folk High Schools as Educational Avant-gardes in Sweden Popular education, power and democracy: Swedish Experiences and Contributions. Leicester: NIACE

Leví- Strauss, C. (1981) Structuralism and myth. The Kenyon Review 4(2): 66-88.

Lewin, K. (1947a) Frontiers in group dynamics: concept, method and reality in social science; social equilibria and social change. Human relations 1(1): 5-40.

Lewin, K. (1947b) Frontiers in Group Dynamics II. Channels of group life; social planning and action research. Human relations 1(2): 143-153.

Liedman, S-E. (2013) Pseudo-quantities, New Public Management and Human Judgement. Confero: Essays on Education, Philosophy and Politics 1(1): 45-66. Linköping: Liu Electronic Press.

Manning White, D. (1950) The Gatekeeper: A case study in the selection of news. Journalism Quarterly 27: 383-90.

Menger, P-M. (1999) Arstistic labor markets and careers. Annual Review of Sociology 25: 541-74

Monson, I. (1996) Saying something: jazz improvisation and interaction. Chicago: University of Chicago Press.

Nicholson, S. (2005) Is jazz dead (or has it moved to a new address)? New York: Routledge.

Nylander, E. (2010) Folkhögskolan som musikaliskt förmak: Om musiklinjer, deras rykte och position. In: F. L. Nilsson and A. Nilsson (eds.) Två sidor av samma mynt? Folkbildning och yrkesutbildning vid de nordiska folkhögskolorna. Lund: Nordic Academic Press, pp. 167-189.

Nylander, E. and Melldahl, A., (forthcoming) "Playing with Capital: On the social selection to jazz school auditioning". Paper to be presented at the $7^{\text {th }}$ European conference of ESREA. 4-7 September 2013, Humboldt University in Berlin, Germany.

Palme, M. (2008) Det kulturella kapitalet: Studier av symboliska tillgångar i det svenska utbildningssystemet 1988-2008. Doctoral dissertation, SEC, Uppsala University.

Palme, M., Lidegran, I. and Andersson, B. (2012) Konststudenter och det kulturella kapitalet. In: M. Gustavsson, M. Börjesson and M. Edling (eds.) Konstens omvända ekonomi. Daidalos: Göteborg Publisher, pp. 111-143.

Perrenoud, M. (2003) La figure du musicos Musiques populaires contemporaines et pratique de masse. Ethnologie française 4(33): 683-689.

Perrenoud, M. (2007) Les musicos: enquête sur des musiciens ordinaires. Paris: Découverte.

Royseng, S., Mangset, P. and Borgen, J. (2007) Young artists and the charismatic myth. International Journal of Cultural Policy 13(1): 1-16

Sapiro, G. (2007) La vocation artistique entre don et don de soi. Actes de la Recherche en Sciences Sociales 3: 4-11 
Sapiro, G. (2010) Introduction. In: G. Sapiro (ed.) Sociology is a Martial Art: Political Writings by Pierre Bourdieu. London: The New Press.

Sapiro, G. (2013) Structural history and crises analysis: The literary field in France during the second World War. In: P. S. Gorski (ed.) Bourdieu and Historical Analysis. Durham: Duke University Press, pp. 266-285.

Schatzki, T. (2012) A primer on practices: Theory and research. In: Higgs, J. et al (eds) Practice-based education: Perspectives and strategies. Rotterdam: Sense Publishers, pp. 13 - 26.

Schatzki, T. R., Cetina, K. K. and von Savigny, E. (2000) The practice turn in contemporary theory. London: Routledge.

Shoemaker, P. J. and Vos, T. (2009) Gatekeeping Theory. New York: Routledge.

Sudnow, D. (2001) [1993] Ways of the Hand. Cambridge, MA: MIT Press.

Stevens, M. L. (2009) Creating a class: College admissions and the education of elites. Cambridge, Mass: Harvard University Press.

Vatin, F. (2013) Valuation as Evaluating and Valorizing. Valuation Studies 1(1): 31-50, Linköping: Liu Electronic Press.

Weber, M. (1998) Ekonomi och Sambälle. Lund: Argos förlag.

Wittgenstein, L. (1966) Lectures and conversations on aesthetics, psychology and religious belief. Oxford: Basil Blackwell.

White, H. C. and White, C. A. (1965) Canvases and careers: institutional change in the French painting world. New York: John Wiley \& Sons.

Whitney, C. and Becker, L. (1982) "Keeping the Gates" for Gatekeepers: The Effects of Wire News. Journalism Quarterly 59(1): 60-65.

Whyton, T. (2010) Jazzicons: Heroes, myths and the jazz tradition. Cambridge: Cambridge University Press.

Zolberg, V. (1995) The Collection Despite Barnes: from Private Preserve to Blockbuster. In: S. Pearce (ed.) Art in Museums. London: The Athlone Press, pp. 94-108. 